\title{
The Renovation Methods Analysis for Current Buildings Air Conditioning Systems
}

\author{
Shuwei Li \\ Department of Power Engineering, School of Energy, Power and Mechanical Engineering, North China \\ Electric Power University, Baoding, Hebei 071003, China
}

\begin{abstract}
There are several problems in air current conditioning system, such as low energy efficiency, equipment aging, low operation efficiency, unnormal function, and poor thermal comfort. In order to better deal these issues, some renovation methods (including installation of ground source heat pump system, changing cold and heat source, reasonable using of displacement ventilation \& natural ventilation, and strengthening the automatic control system) for current building air conditioning were suggested. The results show that the operating and energy efficiency characteristic current air conditioning system could be improved to a great extent through these methods employment.
\end{abstract}

KEYWORD: Building energy-saving, Air conditioning system, Renovation methods, building energy consumption

\section{INTRODUCTION}

Atmospheric concentration of greenhouse gases continues to increase, unless the global fossil fuel consumption greatly reduced (Gao Q, 2009).Global awareness of the serious environmental problems due to fossil fuel consumption increases every year (Sohn B H, 2005).The Heating ventilation and air conditioning (HVAC) systems in buildings account for 33\% of global greenhouse gas emissions in 2010 (Ochsner K, 2008).About a third of the world energy consumption of building and operating according to a study in Griffith and others (Aikins K A, 2012) in atmospheric concentration of greenhouse gases (GHG) continues to increase, unless the global fossil fuel consumption greatly reduced. In China, as we all know, building energy consumption is also an important part of the country's total energy consumption. The building energy consumption in our country has reached more than 30\% (Garber D, 2013). Although our government has begun to enact and enforce the relevant energy efficiency standards since the 1980, the whole building energy-saving progress is still very slow (Liu Z, Xu W, 2015). Most of the existing buildings is still a high-energy buildings which will be a threat to the future ecological environment (Geng Y, 2013). Therefore, it is important and necessary to perform the energy saving works for existing buildings. In China, it was estimated that heating, ventilation and air-conditioning (HVAC) systems accounted for about $65 \%$ of the energy consumption in the buildings. In order to bet- ter improve the current air conditioning performance, some renovation methods(including installation of ground source heat pump system, changing cold and heat source, reasonable using of displacement ventilation \& natural ventilation, and strengthening the automatic control system) for current building air conditioning were suggested.

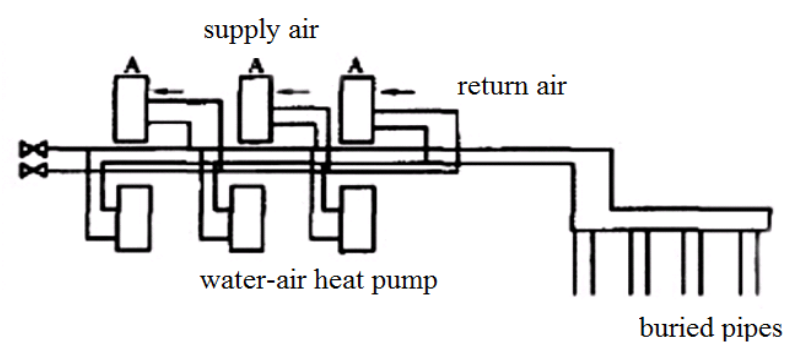

Fig.1 The schematic diagram of ground source heat pump

\section{GROUND SOURCE HEAT PUMP TECHNOLOGIES IN CURRENT BUILDING ENERGY SAVING}

\subsection{The composition and principle of ground source heat pump.}

Conventional ground source heat pump system and general heat pump system has the same basic components, including the water-air pump in the building, circulation pump, indoor water piping constitut- 
ing. Figure 1-1 shows a ground source heat pump system. The city equipment is similar to water loop heat pump system and the city of external water system consists of underground pipe system to replace the cooling tower, boiler, auxiliary pumps and heat exchangers. Condenser cold provides heat quantity of soil heat exchanger. The ground source heat pump (GSHP) schematic diagram is shown in Fig.2.

\section{GROUND SOURCE HEAT PUMP RENOVATION PROJECT}

\subsection{Background of the project.}

The renovation project of the entity belongs to the office building renovation project, the total construction area of $3593 \mathrm{~m}^{2}$, and the building shape coefficient is 0.256 . The building was toward the north and south orientation. The main framework for this building was reinforced concrete structure. And the total height of this building was $25 \mathrm{~m}$. The first layer of this building was used for shop and the secondsix layers were used for office. The outer envelope was made of solid clay brick masonry, which was $240 \mathrm{~mm}$. And the roofing of this building was made of cast-in-situ concrete, insulation layer and aerated concrete block. The whole outer window is a single glass plastic window and the ratio of window to wall was 0.24 . The ratio of window to wall different orientation was 0.11 (east), 0.29 (south), 0.04(west) and 0.26 (north), respectively.

No central air conditioning system was used in the building when renovation was conducted. It is not easy to manage due to decentralized heat-supply. The central air conditioning system cooling and heat sources employ the renewable geothermal resources, which could save a lot fossil energy (Wenzhong B Z, 2004).

\section{SOLUTION.}

The scope of the load calculation for JianKe institute building included 2-6 layers. There were 22 offices on each floor, and an average of three staff work in each office. The fresh air volume for each person is $30 \mathrm{~m}^{3} / \mathrm{h}$, and the energy consumption is shown in Table 1-1.

Table.1 The office building energy consumption in winter and summer

\begin{tabular}{|c|c|c|}
\hline Energy Category & $\begin{array}{c}\text { Energy Consump- } \\
\text { tion }(\mathrm{kW} / \mathrm{h})\end{array}$ & $\begin{array}{c}\text { Energy consump- } \\
\text { tion per unit area }\end{array}$ \\
\hline $\begin{array}{c}\text { Air-conditioning } \\
\text { power consumption }\end{array}$ & 227305 & 63.91 \\
\hline $\begin{array}{c}\text { The heating } \\
\text { power } \\
\text { consumption }\end{array}$ & 91309 & 26.07 \\
\hline Total & 318614 & 90.98 \\
\hline
\end{tabular}

The Specific programs are conducted as follows:

(1)Thermal equilibrium solution

According to information by reference, load unbalance of ground source heat pump system (GSHP) should be controlled below 10\%.According to the calculation of the energy consumption of the system software; we found the load unbalance rate was about 59.8\% now, which was much higher than the usual value. The program will employ two ways to reduce the imbalance in order to reach within a predetermined value at last.

a) Increasing heating area in winter

According to the simulation results, the summer office building energy consumption is $227305 \mathrm{kWh}$, and the winter energy consumption is $93309 \mathrm{kWh}$. After expanding the area of winter heating air conditioning system, the energy consumption calculation was $122705 \mathrm{kWh}$ because the winter heating area has expand to $3835 \mathrm{~m}^{2}$, which was greater than the summer cooling area of $2987 \mathrm{~m}^{2}$. The heat which discharged into the soil for at this time in summer was about 227305kWh. The cold which extracted from the soil was about $146014 \mathrm{kWh}$. A part of heat was used to produce the domestic hot water in summer, thus less hot was discharged into the soil. These effective measures could keep the balance between summer and winter.

b) Preparation of free hot water in summer and winter

By heat recovery function of ground source heat pump in summer, recycling part of the exhaust heat was used to heat hot water during refrigeration while reducing exhaust heat system. In winter, the function of ground source heat pump was used to recover the total heat, and further to absorb more heat from the soil for heating domestic hot water, in order to achieve further load balancing.

Economic Comparisons. This paper is divided into two aspects: the economical comparison of the main initial investment and operating cost comparisons. According to the requirement of the building in order to improve the office environment, it is necessary to acquire the central air conditioning system, compare the ground source heat pump system with the VRV system initial investment and operation cost, operation cost includes: unit operation cost and for making hot water, waste heat utilization cost comparison based on the following assumptions: (1) operating earnings and payback period based on the comparison of the fission air conditioning system;(2) the fission unit without the use of variable frequency, load rate are calculated according to $100 \%$, other central air conditioning system according to their hair statistical load rate; Pet-name ruby summer boot for 120 days, ten hours a day, boot than 0.8 , winter boot for 120 days, ten hours a day, boot ratio 0.5, specific results are shown in table 1 and 2.This paper is divided into two aspects: the economical comparison of the main initial investment and operating cost 
comparisons. According to the requirement of the building in order to improve the office environment, it is necessary to acquire the central air conditioning system, compare the ground source heat pump system with the VRV system initial investment and operation cost, operation cost includes: unit operation cost and for making hot water, waste heat utilization cost comparison based on the following assumptions[8]: (1) operating earnings and payback period based on the comparison of the fission air conditioning system; (2) the fission unit without the use of variable frequency, load rate are calculated according to $100 \%$, other central air conditioning system according to their hair statistical load rate; Pet-name ruby summer boot for 120 days, ten hours a day, boot than 0.8, winter boot for 120 days, ten hours a day, boot ratio 0.5 , specific results are shown in table 2 .

Table 2 economic comparison

\begin{tabular}{|c|c|c|c|c|}
\hline $\begin{array}{c}\text { System } \\
\text { forms }\end{array}$ & $\begin{array}{c}\text { Initial } \\
\text { Investment } \\
\text { (RMB) }\end{array}$ & $\begin{array}{c}\text { Unit } \\
\text { operating } \\
\text { costs(RMB) }\end{array}$ & $\begin{array}{c}\text { Making hot } \\
\text { water } \\
\text { and some } \\
\text { waste } \\
\text { heat utiliza- } \\
\text { tion } \\
\text { fee (RMB) }\end{array}$ & $\begin{array}{c}\text { Total } \\
\text { operating } \\
\text { costs(RMB) }\end{array}$ \\
\hline $\begin{array}{c}\text { VRV+ } \\
\text { Electric } \\
\text { boiler }\end{array}$ & 75000 & 64534 & 66178 & 130712 \\
\hline $\begin{array}{c}\text { Ground } \\
\text { source } \\
\text { heat } \\
\text { pump }\end{array}$ & 120000 & 49642 & 0 & 49642 \\
\hline
\end{tabular}

\section{CONCLUSION}

(1) It has obvious advantages than other forms of air conditioning systems by using constant temperature field of the ground from the perspective of economic benefits.

(2) For hot summer and warm winter area, there were some different loading; the employment of the ground source heat pump can be resolved load distribution unbalance. The wasting heat can be used to produce domestic hot water.

(3) This project solves these problems by increasing the heat balance of the winter heating area, which not only increases the thermal comfort area, but also provide a good solution for similar projects.

\section{REFERENCES}

Aikins K A, Choi J M. Current status of the performance of GSHP (ground source heat pump) units in the Republic of Korea[J]. Energy, 2012, 47(1): 77-82.

Garber D, Choudhary R, Soga K. Risk based lifetime costs assessment of a ground source heat pump (GSHP) system design: Methodology and case study[J]. Building and Environment, 2013, 60: 66-80.
Gao Q, Li M, Yu M, et al. Review of development from GSHP to UTES in China and other countries[J]. Renewable and Sustainable Energy Reviews, 2009, 13(6): 1383-1394.

Geng Y, Sarkis J, Wang X, et al. Regional application of ground source heat pump in China: a case of Shenyang[J]. Renewable and Sustainable Energy Reviews, 2013, 18: 95102.

Ochsner K. Carbon dioxide heat pipe in conjunction with a ground source heat pump (GSHP)[J]. Applied Thermal Engineering, 2008, 28(16): 2077-2082.

Liu Z, Xu W, Qian C, et al. Investigation on the feasibility and performance of ground source heat pump (GSHP) in three cities in cold climate zone, China[J]. Renewable Energy, 2015, 84: 89-96.

Sohn B H, Cho C S, Shin H J, et al. Cooling and heating performance evaluation of a GSHP system[J]. Korean Journal of Air-Conditioning and Refrigeration Engineering, 2005, 17(1): 71-81.

Wenzhong B Z, Jianxing L, Guangbei T. Prospect of sewage source heat pump systems and cooling and heating energy utilization of sewage [J][J]. Hv \& Ac, 2004, 8: 006. 